\title{
ЛИТОЛОГИЯ
}

УДК 552.54:552.53

\section{Литология нижнепермских карбонатных и сульфатных эвапоритов района «классического» кунгура (Пермский край)}

\author{
Т.А. Калинина \\ Горный институт УрО РАН, 614007, Пермь, ул. Сибирская, 78a \\ E-mail: tatyanaak89@mail.ru \\ (Статья поступила в редакцию 3 июня 2015 г.)
}

\begin{abstract}
Литологическое изучение карбонатных и сульфатных эвапоритов района «классического» кунгура на территории Пермского края позволило показать, что данный комплекс пород сформировался в течение пяти циклов развития эвапоритового бассейна, которое завершилось его полным усыханием (исключение составила территория Соликамской впадины). Смена тонкослоистого пелитоморфного или массивного оолитового доломита шевронной, массивной, желваковой и линзовидно-желваковой сульфатной породой в пределах ритмопачки может свидетельствовать о закономерном изменении концентрации вод бассейна в течение одного цикла. Выдержанное строение ритмопачек и их неоднократное чередование в разрезе нижнепермских эвапоритов говорят об осадконакоплении в обширном мелководном, периодически опресняющемся бассейне. Установлено, что текстура сульфатов формируется на стадии седиментации и диагенеза и зависит от содержания несульфатного материала в породе и анизотропии минералообразующей среды. Литологические особенности строения более молодых соликамских соляно-мергельных отложений, сформировавшихся после отложений хлоридных солей в Соликамской впадине, позволяют предполагать их образование в условиях, близких к современным себхам.

Ключевые слова: Пермский край, карбонатные и сульфатные эвапориты, литология, иренская свита, кунгур.
\end{abstract}

DOI: $10.17072 /$ psu.geol.28.6

\section{Введение}

Карбонатно-сульфатные эвапориты района "классического" кунгура приурочены к восточной окраине ВосточноЕвропейской платформы и Предуральскому краевому прогибу. В стратиграфическом отношении они охватывают верхнюю часть филипповской свиты филипповского горизонта и иренскую свиту иренского горизонта кунгурского яруса, а также нижнюю часть соликамской свиты соликамского горизонта уфимского яруса. В строении иренской свиты иренского горизонта выделяются три карбонатные (неволинская, елкинская, тюйская) и четыре сульфатные (ледянопещерская, шалашнинская, демидковская, лунежская) пачки (таблица) [12]. 
Переслаивание карбонатных и сульфатных слоев в разрезе кунгурских эвапоритов позволяет выделить пять ритмопачек, каждая из которых начинается с доломитов, сменяющихся гипсами или ангидритами в отличие от традиционной схемы [12]. Такая последовательность отвечает циклу развития эвапоритового бассейна. Сопоставление мощностей показало, что в целом вверх по стратиграфическому разрезу происходит уменьшение мощности карбонатных пачек и увеличе- ние - сульфатных, что свидетельствует о регрессии моря и общем повышении солености вод кунгурского палеобассейна. Некоторое увеличение мощности тюйских доломитов является результатом временного распреснения лагуны. Такие особенности формирования кунгурских эвапоритов уже отмечались ранее $[2,3,6,8,10$, 18]. Соликамские соляно-мергельные отложения сформировались в начальный период трансгрессивного цикла раннепермского моря, когда шло постепенное

Стратиграфия и литология нижнепермских карбонатно-сульфатных эвапоритов

\begin{tabular}{|c|c|c|c|c|c|c|c|}
\hline \begin{tabular}{|l} 
Сис- \\
тема
\end{tabular} & $\begin{array}{l}\text { Oт- } \\
\text { дел }\end{array}$ & Ярус & Горизонт & Свита & Пачка & $\begin{array}{c}\text { Мощность, } \\
\text { м }\end{array}$ & $\begin{array}{c}\text { Литологический } \\
\text { состав }\end{array}$ \\
\hline \multirow{11}{*}{ 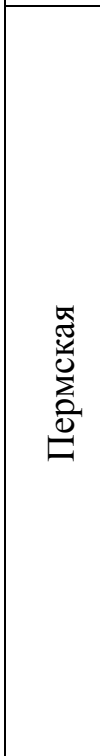 } & \multirow{11}{*}{ 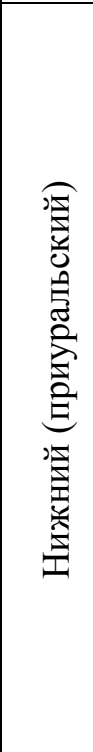 } & 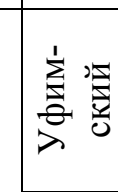 & 仓 & 它 & $\begin{array}{c}\text { Соляно- } \\
\text { мергельная }\end{array}$ & $15-160$ & $\begin{array}{l}\text { Мергели, глинисто- } \\
\text { карбонатно- } \\
\text { сульфатная и мер- } \\
\text { гель-гипсовая породы }\end{array}$ \\
\hline & & \multirow{10}{*}{ 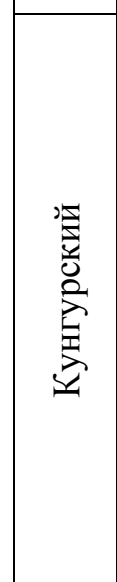 } & \multirow{9}{*}{ 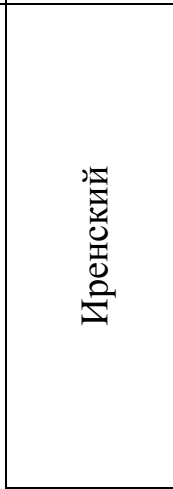 } & \multirow{9}{*}{ 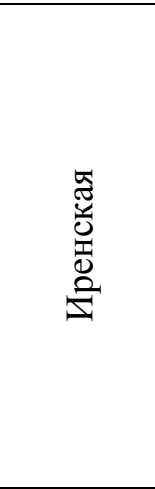 } & Лунежская & $46-74$ & Гипс/ангидрит \\
\hline & & & & & Тюйская & $4-14$ & Доломит \\
\hline & & & & & Демидковская & $25-30$ & Гипс/ ангидрит \\
\hline & & & & & Елкинская & $2-4$ & Доломит \\
\hline & & & & & Шалашнинская & $12-35$ & Гипс/ангидрит \\
\hline & & & & & \multirow{3}{*}{ Неволинская } & до 3 & Доломит \\
\hline & & & & & & до 6,5 & Гипс/ангидрит \\
\hline & & & & & & до 4,5 & Доломит \\
\hline & & & & & Ледянопещерская & $30-35$ & Гипс/ангидрит \\
\hline & & & $\begin{array}{l}\text { Филип- } \\
\text { повский }\end{array}$ & $\begin{array}{l}\text { Филип- } \\
\text { повская }\end{array}$ & & $50-70$ & Доломит \\
\hline
\end{tabular}

распреснение реликтовой кунгурской палеолагуны. Резкая вертикальная и латеральная фациальная изменчивость толщи свидетельствует о непостоянстве условий седиментации в раннесоликамское время. Практически на всей территории Пермского края карбонатно-сульфатный разрез нижнепермских эвапоритов перекрыт толщей более молодых терригеннокарбонатных пород и выходит на дневную поверхность лишь в районе Уфимского вала, Косьвинско-Чусовской седловины и в отдельных локальных поднятиях Соликамской впадины. Такое геологическое положение карбонатно-сульфатных эвапоритов кунгура обусловило отсутствие единого разреза, который вскрывал бы их полностью. Карбонатно-сульфатные эвапориты изучались нами на шести разрезах, позволивших составить единый сводный разрез (рис. 1). Суммарная мощность изученных разрезов составила около 3000 м, сделано детальное описание более 300 образцов, представляющих различные структурно-текстурные разности карбонатно-сульфатных эвапоритов. При выполнении работы проведено оптикомикроскопическое исследование 35 шлифов (поляризационный микроскоп проходящего и отраженного света Axioskop 40 Pol (Carl Zeiss), ГИ УрО РАН, г. Пермь). 


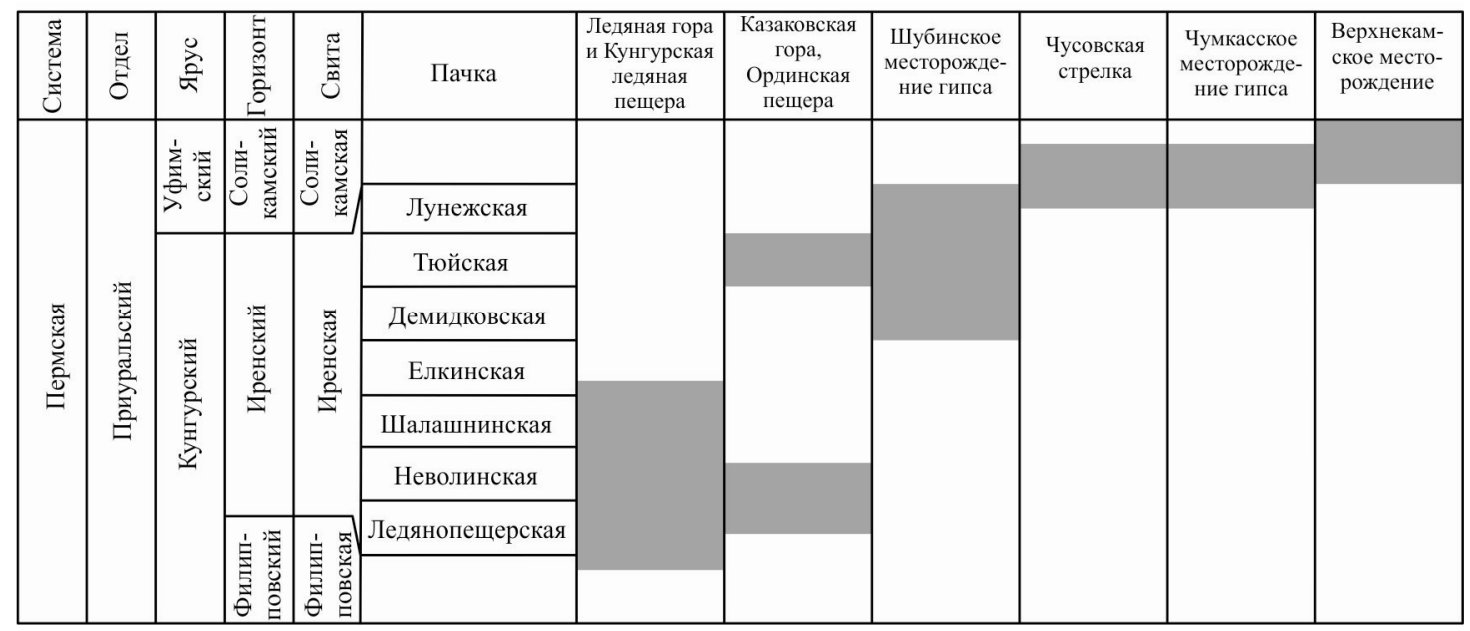

Рис. 1. Объекты исследования

Литологическая характеристика карбонатных и сульфатных пачек

\section{Кунгурский ярус}

Породы филипповской свиты филипповского горизонта изучались на обнажениях близ одноименного села (рис. 2,a) и по керну скважины "Ледяная гора". Разрез начинается с желтовато-серых тонкослоистых доломитов, характеризующихся тонкой плитчатой и кубоидной отдельностью, изредка прослеживаются горизонты с пустотами от выщелоченных раковин брахиопод. Выше залегает светлокоричневый пелитоморфный известняк с множественными органическими остат- ками, среди которых преобладают двустворки, реже встречаются брахиоподы и гастроподы [19]. Заканчивается разрез филипповских карбонатов светло-серыми доломитами, которым, в отличие от подстилающих известняков, присуща отчетливая слоистость - от 30-40 см в нижней части до 5-10 см в верхней. На контакте с вышележащими сульфатами иренской свиты доломит характеризуется ритмичной слоистостью (рис. 2,б): плотные тонкослоистые прослои (мощность около 22,5 см) с пелитоморфной структурой переслаиваются с массивными мелкозернистыми, нередко пористыми (мощность прослоев до 4-4,5 см).
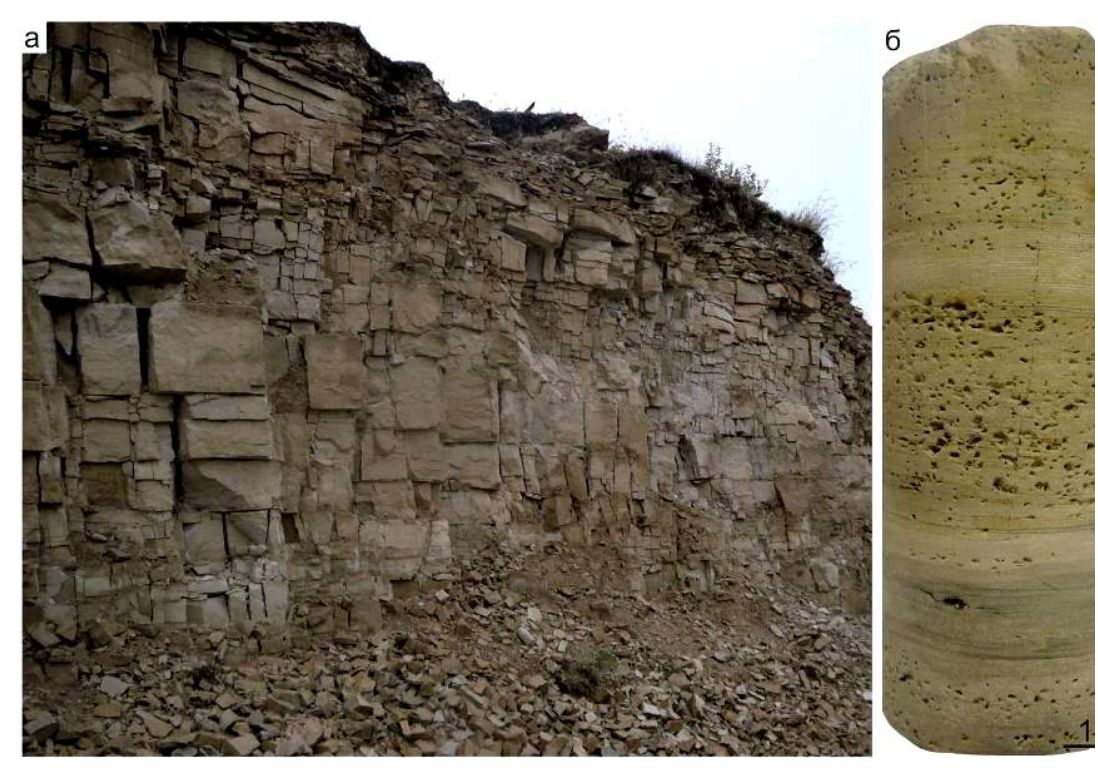

Рис. 2. Доломит $ф u-$ липповской свиты: $а$ обнажение в районе с. Филипповское; $б$ ритмичная слоистость доломита на контакте с ледянопещерскими сульфатами 


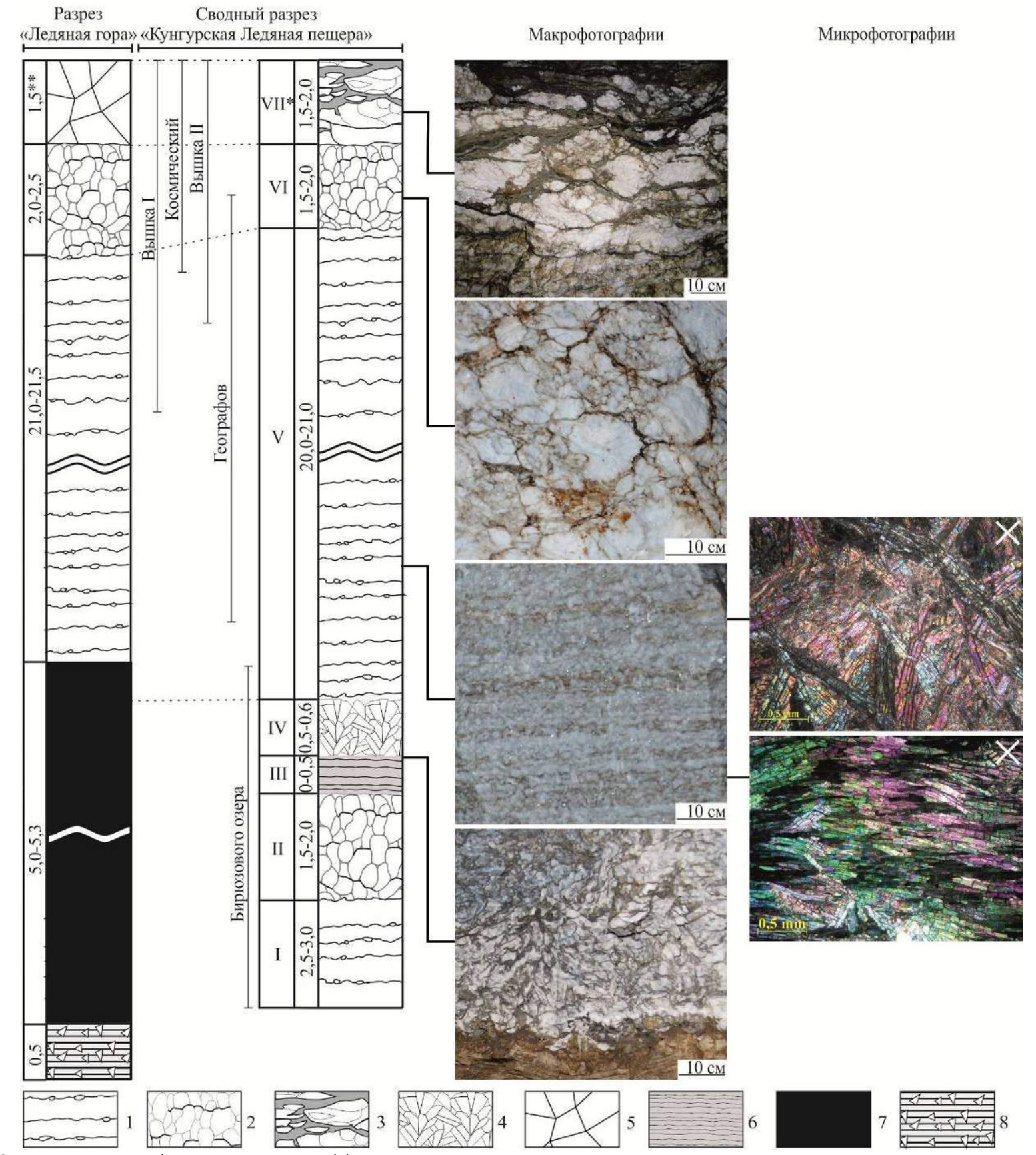

Здесь и далее: *- номер слоя, **-мощность слоя

Рис. 3. Литологический разрез ледянопещерской пачки: 1-5 - текстурно-структурные типы сульфатов (1 - массивные; 2 - желваковые; 3 - линзовидно-желваковые; 4 - с реликтовым шевронным строением; 5 - гигантокристаллические); 6 - тонкослоистый доломит; 7 - карстовая полость; 8 - карстово-обвальные отложения

Предполагается, что появление пор и перекристаллизация доломита связаны с выщелачиванием сульфатных минералов (гипса или ангидрита).

В строении иренской свиты иренского горизонта выделяются три карбонатные (неволинская, елкинская, тюйская) и четыре сульфатные (ледянопещерская, ша- лашнинская, демидковская, лунежская) пачки.

Сульфаты ледянопещерской пачки изучались в разрезе скважины "Ледяная гора" и на обнажениях в гротах Кунгурской ледяной пещеры (Вышка I, Вышка II, Космический, Географов, Бирюзового озера). Изучение структурно-текстурных особен- 
ностей пород ледянопещерской пачки позволило выделить 7 слоев (рис. 3).

Нижняя часть пачки, непосредственно контактирующая с филипповскими доломитами, сильно закарстована, а реликтовые фрагменты сульфатной породы, отмеченные в карстово-обвальных отложениях, сложены гигантокристаллическим гипсом. Выше карстовой полости пачка сложена неяснослоистой, массивной мелкозернистой гипс-ангидритовой породой (слой 1) с неясно выраженным желваковым строением (размер желваков не превышает 1-1,5 см). Отмеченные здесь небольшие включения глинистокарбонатного материала приурочены преимущественно к краевым частям прослоев, реже желвакам. Выше по разрезу количество глинисто-карбонатного материала в породе постепенно увеличивется (до $10 \%$ ) и очертания желваков становятся более четкими (размер стяжений колеблется от 3 до 10-15 см) - массивная текстура породы сменяется на желваковую (слой 2). Желваки сульфатов в поперечном разрезе характеризуются округлой формой, тогда как в продольном они вытянуты по вертикали и расширяются от основания к вершине. По взаимоотношению желваков и глинисто-карбонатного материала, максимальные концентрации которого приурочены к основанию стяжений сульфатов, на отдельных участках наблюдается "теневое" слоистое строение породы.

Слой 3 не выдержан по мощности (550 см) и нередко выклинивается. Он сложен плотным пелитоморфным коричневато-бежевым доломитом с тонкослоистой текстурой. Кровля прослоев неровная изза включений (до 10 см) сульфатов сложной формы.

Слой 4 представлен мелкозернистой гипс-ангидритовой породой с реликтовым шевронным строением. Размер отдельных индивидов, чьи очертания подчеркиваются включениями глинисто-карбонатного материала, достигает 20-25 см. Выше по разрезу залегает массивная порода (слой 5), которая по структурно-текстурным особенностям соответствует гипсангидритовой породе слоя 1. В зависимости от удаленности от склона состав породы меняется от существенно гипсового до гипс-ангидритового и ангидритового. Ангидрит представлен агрегатами длиннопризматических и шестоватых кристаллов, образующих радиально-лучистые и веерообразные пучки. Контур таких агрегатов нередко окаймлен глинистокарбонатным материалом. На отдельных участках ангидритовая порода имеет блочно-линзовидное строение: по периферии таких блоков пучки кристаллов ангидрита ориентированы согласно контуру, а внутри расположены хаотически или образуют агрегат параллельношестоватого строения.

Как и на границе 1 и 2 слоев, к кровле ледянопещерской пачки содержание глинисто-карбонатного материала постепенно увеличивается, и массивная текстура мелкозернистой ангидрит-гипсовой породы сменяется на желваковую (слой 6 , являющийся структурно-текстурным аналогом слоя 2), а затем линзовидножелваковую (слой 7). Слагающие линзы желваки разные: в центре они округлые, изометричные, а по периферии - более крупные линзовидные и ориентированные согласно слоистости.

Неволинская пачка изучалась по керну скважины "Ледяная гора" и в гротах Кунгурской ледяной пещеры (Вышка I, Вышка II, Космический). Она сложена доломитами с мощным прослоем гипса в центральной части (рис. 4).

Нижний доломитовый прослой начинается с тонко-, среднеслоистой пелитоморфной породы (слой 1), отдельные прослои которой насыщены оолитами зонального строения: пелитоморфное ядро (иногда с включениями гипса) и тонкая (1-4 зоны) оболочка. Размер оолитов редко превышает 0,2-0,5 мм. В нижней части слоя отмечаются небольшие линзы, реже гнезда и отдельные желваки (до 1,5 см) мелкозернистого гипса. Залегающий выше по разрезу доломит массивный с оолитовой структурой (слой 2). Ооиды разме- 


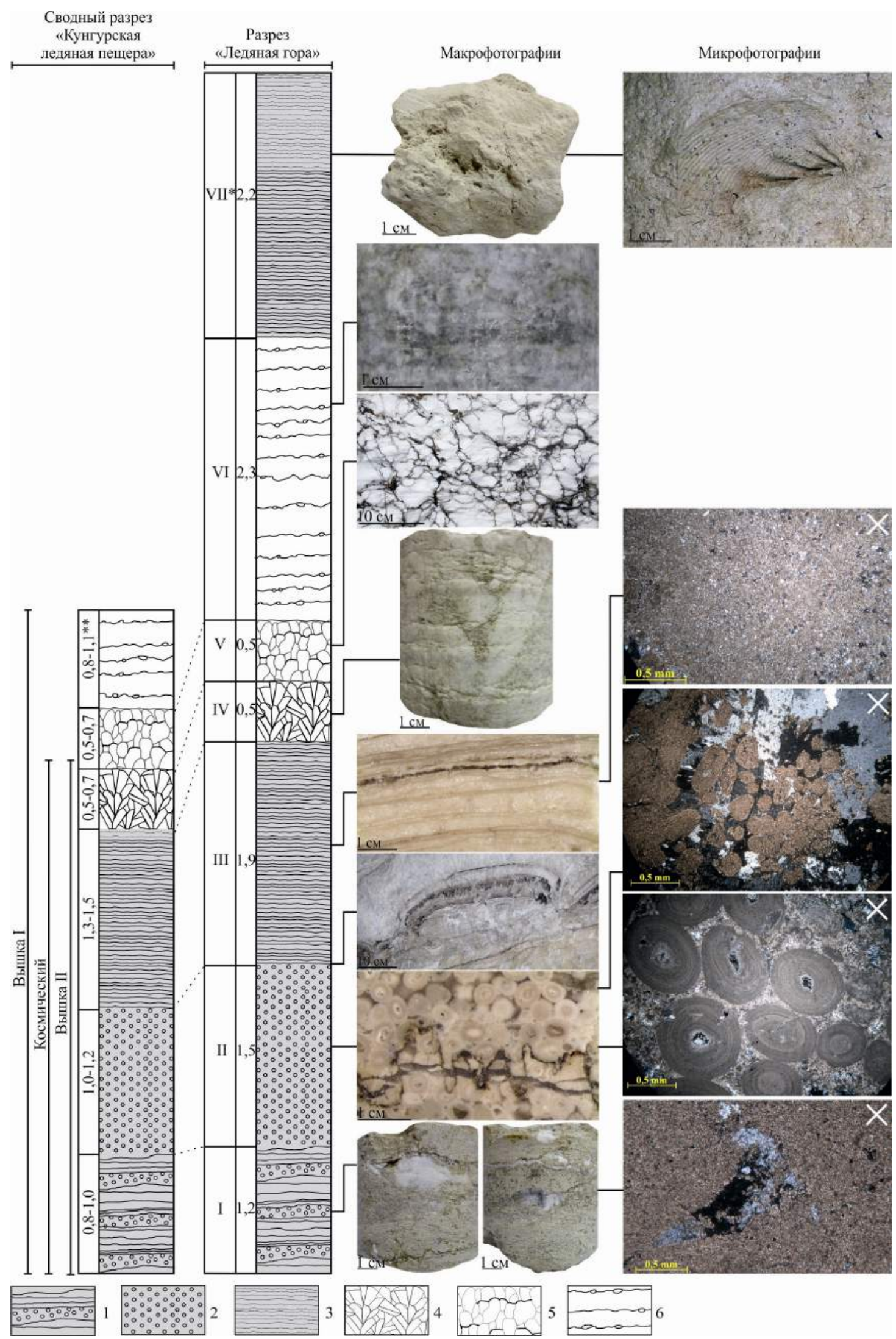

Рис. 4. Литологический разрез неволинской пачки: 1-3 - текстурно-структурные типы доломита (1 - переслаивание оолитового и пелитоморфного; 2 - оолитовый; 3 - тонкослоистый пелитоморфный); 5-6 - текстурно-структурные типы сульфатов (4 - с реликтовым шевронным строением; 5 - желваковые; 3 -массивные) 
Разрез
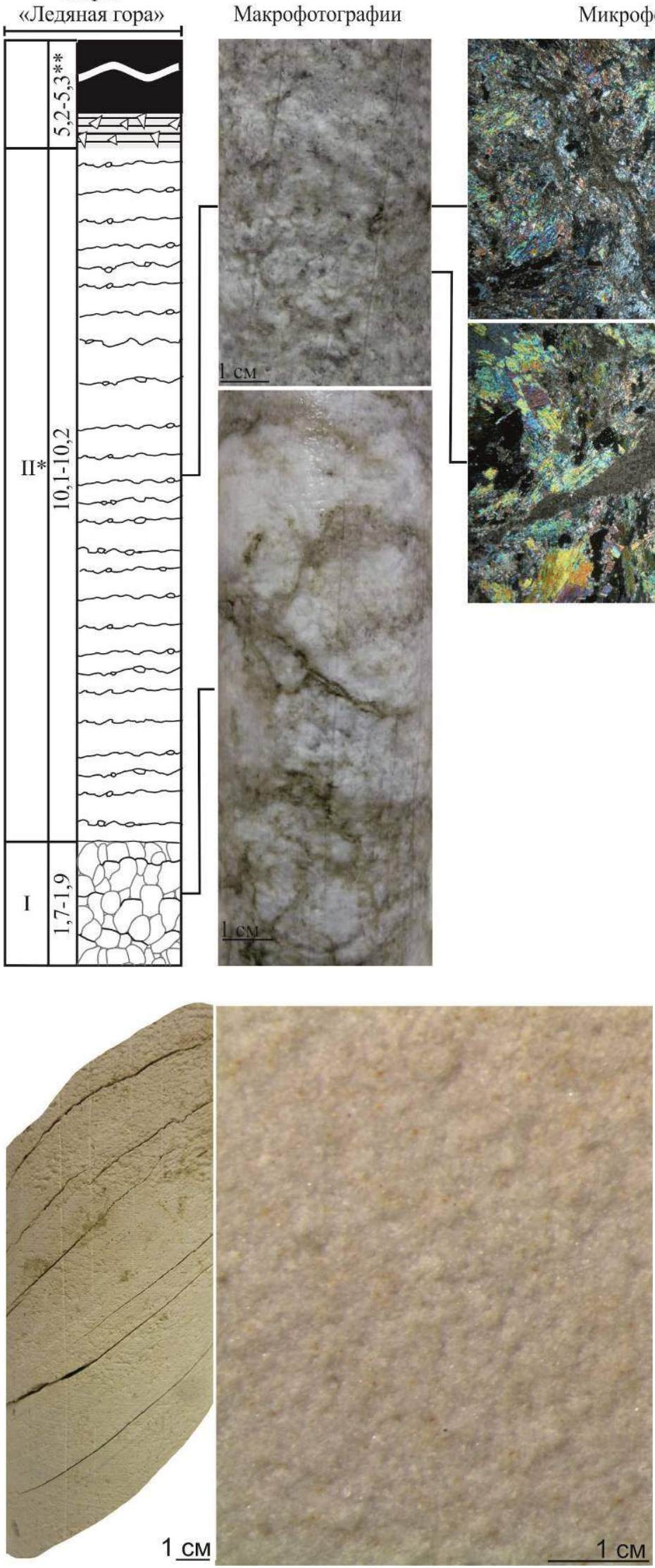

Рис. 5. Литологический разрез шалашнинской пачки: 1-2 текстурно-

структурные типь сульфатов (1 - желваковые; 2 - массивные); 3 - карстовая полость; 4 - карстово-обвальные отложения
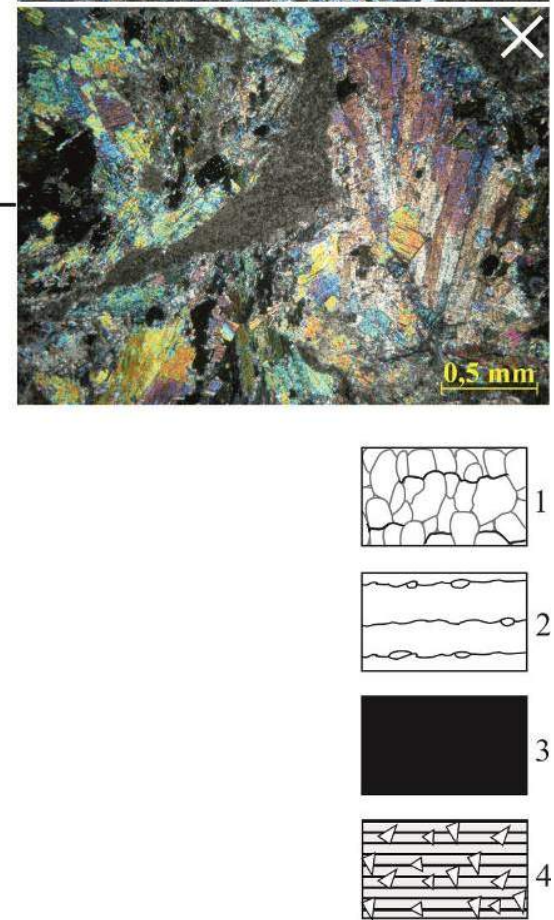

Рис. 6. Пелитоморфный доломит елкинской пачки

ром 1-1,2 мм характеризуются четкой концентрической зональностью - в сред- нем в каждом насчитывается 5-6 зон, реже до 10-12. Центральная часть ооидов не- 
редко выщелочена. В качестве цемента на отдельных участках выступает пелитоморфный доломит, а на других - пойкилитовый гипс. Также отмечены участки, где интерстиции между оолитами выполнены кальцитом. Строение оолитового доломита осложнено небольшими стилолитовыми швами. Заканчивается нижний прослой тонкослоистым пелитоморфным доломитом (слой 3), в подошве которого зафиксированы строматолитоподобные постройки (до 40-45 см). Их нижняя часть сложена сложным гипс-кальцитдоломитовым агрегатом с пятнистой текстурой, а верхняя - тонкослоистым доломитом с редкими оолитами и раковинами моллюсков. В центральной части постройки наблюдается субслоистая зона окремнения, нижняя граница которой характеризуется неровным заливообразным контуром, а верхняя - ровным.

В основании гипсового прослоя неволинской пачки залегает мелко-, среднезернистая порода с реликтовым шевронным строением (слой 4). Интерстиции между шевронными кристаллами (размер не более 20-30 см) выполнены глинистокарбонатным материалом. Залегающий выше по разрезу гипс (слой 5) характеризуется желваковой текстурой. В нижней части слоя, где количество глинистокарбонатного вещества больше (10-12\%), желваки крупные (до 10 см) овальные с субвертикальной ориентировкой. Выше их размер уменьшается, и форма становится более округлой. В кровле гипсового прослоя текстура породы крупнослоистая до массивной (слой 6).

Верхний доломитовый прослой сложен тонкослоистой до массивной пелитоморфной породой (слой 7), в которой отмечаются фрагменты раковин моллюсков и небольшие стилолитовые швы. В кровле слоя доломит пористый с множественными кавернами выщелачивания, которые, вероятно, свидетельствуют о былом присутствии сульфатов.

Шалашнинская пачка изучалась в разрезе скважины "Ледяная гора", где ее верхняя часть разрушена (рис. 5).
В подошвенной части пачка сложена мелкозернистым гипсом с желваковой текстурой (слой 1). Желваки (видимый в керне размер не более 5-7 см) характеризуются округлой, реже овальной, формой, подчеркиваемой каймой глинистокарбонатного состава.

Выше по разрезу текстура породы, состав которой меняется от ангидритгипсового в нижней части слоя до гипсового в верхней, сменяется на массивную (слой 2). Петельчатый характер распределения глинисто-карбонатного материала подчеркивает нечетко выраженное желваковое строение породы. Реликтовый ангидрит отмечен в виде "вееров" и радиально-лучистых агрегатов длиннопризматических кристаллов, которые на одних участках расположены хаотически, а на других - ориентированы в одном направлении. Основание некоторых "вееров" приурочено к глинисто-карбонатному материалу.

Елкинская пачка на изученных разрезах вскрывается не полностью, а лишь в виде отдельных фрагментов (разрез "Ледяная гора") (рис. 6). В предыдущих работах [12] показано, что пачка сложена тонкослоистым пелитоморфным известковистым доломитом с маломощными (до 5-10 см) прослоями ангидрита в кровле. В нижней части прослоя доломит нередко оолитовый. Порода пористая - интерстиции часто заполнены гипсом.

Демидковская пачка изучалась на Шубинском гипсовом карьере, где вскрываются ее центральная и кровельная части.

Разрез демидковских сульфатов (рис. 7) начинается с массивной ангидритовой породы (слой 1), насыщенной включениями глинисто-карбонатного материала, которые обуславливают ее пятнистую текстуру. Ангидрит представлен длиннопризматическими (до 1 мм) индивидами, формирующими веерообразные и радиально-лучистые агрегаты. Изредка отмечаются образования, в центральной части которых ангидрит мелкозернистый (до 0,01 мм) со спутанно-волокнистой 
Разрез

«Шубинский

гипсовый карьер»

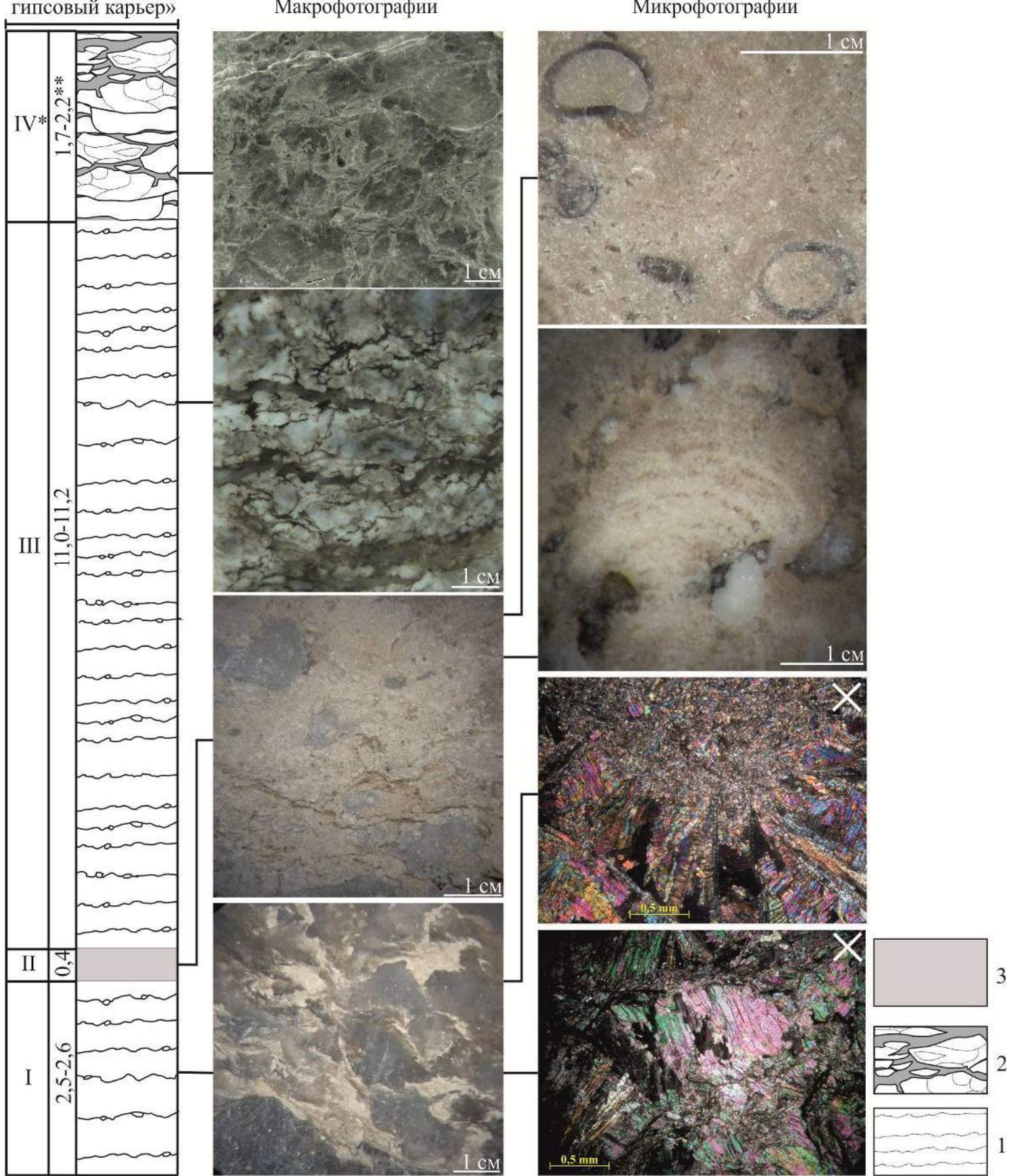

cM

\section{.} .

Рис. 7. Литологический разрез демидковской пачки: 1-2 - текстурно-структурные типь сульфатов (1 -массивные; 2 - линзовидно-желваковые); 3 - доломит с пятнистой текстурой

структурой, которая к периферии постепенно сменяется более крупнозернистой (до 0,5 мм) пучковидно-веерообразной. Аналогичная смена структуры ангидрита отмечается и вдоль глинисто-карбонатных включений. Кроме того, отмечены участки, где отдельные пучки ангидрита ориентированы и образуют пологоволнистые пересекающиеся друг с другом прожилки, которые придают породе блочнолинзовидное строение.

Слой 2 представлен доломитом с пятнистой текстурой: реликтовые фрагменты пелитоморфного доломита погружены в агрегат с микро-, мелкозернистой структурой. Слой не выдержан по мощности и нередко выклинивается. Кровля слоя неровная, заливообразная за счет множественных включений сульфатов. В доломите 
отмечаются небольшие (до 1 см) строматолитоподобные постройки и фрагменты раковин моллюсков.

Залегающий выше по разрезу слой 3 сложен неяснослоистой ангидритгипсовой породой с глинистокарбонатным материалом. Последний, наряду с фрагментами прослоев, отмечен в виде рассеянных включений. На общем сером фоне отмечаются небольшие (до 1,5 см) белые желваки гипса. В кровельной части слоя содержание глинистокарбонатных включений постепенно увеличивается.

Завершается разрез демидковской пачки гипсовой породой с ярко выраженным линзовидно-желваковым строением (слой 4). Разрез
«Шубинский гипсовый карьер»

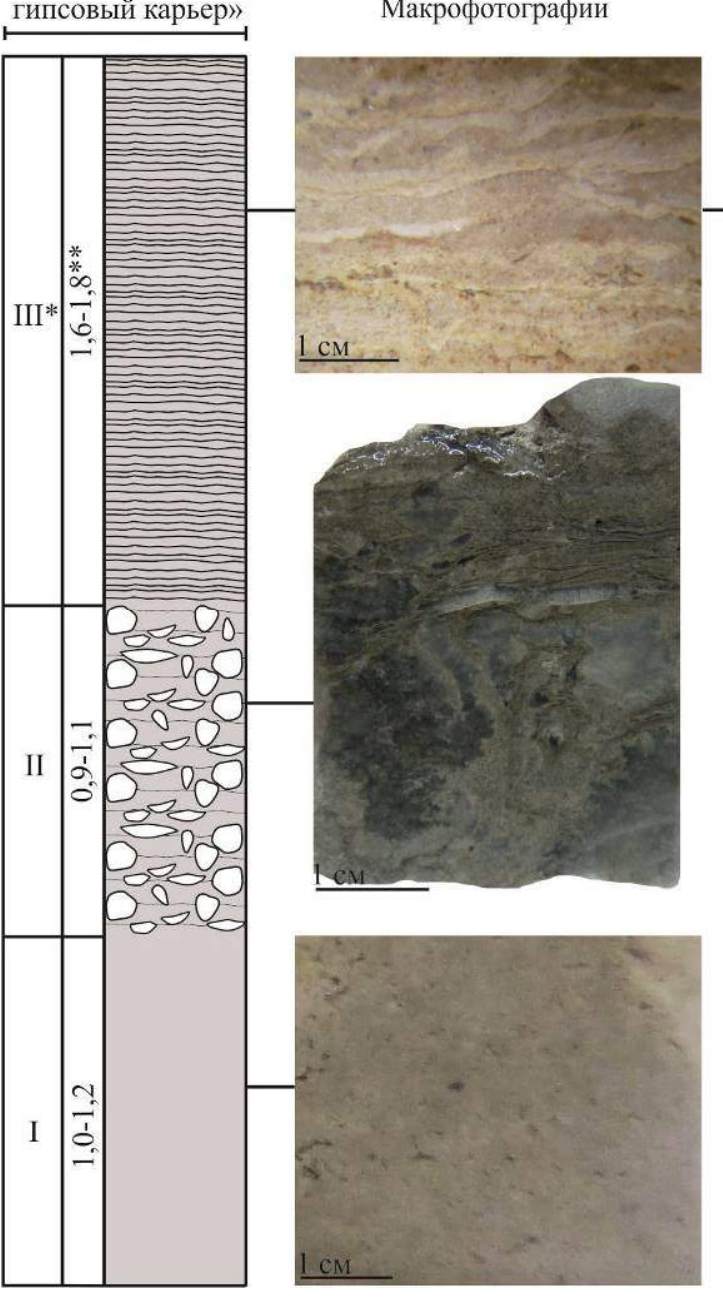

Тюйская пачка изучалась в карьере Шубинского месторождения гипса (рис. 8). Ее разрез начинается с массивного пелитоморфного доломита (слой 1), который вверх по разрезу сменяется среднеслоистой доломит-гипсовой породой (слой 2), a затем - тонкослоистой доломитовой (слой 3). Доломит тонкопористый, интерстиции нередко заполнены пойкилитовым гипсом. В центральной части пачки (слой 2) строение слоя линзовидное и желваковое (до 2,5 см). Желваки сложены мелкозернистым гипсом, вытянуты по вертикали и характеризуются неровным заливообразным контуром, каплевидной (расширяются от основания в вершине), реже округлой, формой. 
В основании пачки (рис. 9) залегает мелкозернистая ангидрит-гипсовая порода с реликтовым шевронным строением (слой 1) - размер сдвойникованных кристаллов иногда достигает 30-45 см. Выше по разрезу - неяснослоистая до массивной ангидрит-гипсовая порода (слой 2) с нечетким желваковым строением (размер желваков достигает 1-1,5 см). Ангидрит отмечен в виде веерообразных и сноповидных агрегатов длиннопризматических зерен. К кровле пачки содержание глинисто-карбонатного материала увеличивается, и текстура сульфатов сменяется на желваковую (слой 3 ).
Уфимский ярус

Породы соликамской свиты соликамского горизонта изучались нами по материалам керна скважин, пробуренных в надсолевой толще Верхнекамского месторождения солей, а также в карьере Чумкасского гипсового месторождения и разрезе "Чусовская стрелка".

В пределах Верхнекамского месторождения солей соликамская свита подразделяется на соляно-мергельную (наиболее поздние эвапориты нижней перми) и терригенно-карбонатную толщи. Соляномергельная толща сложена чередующимися в разрезе и фациально сменяющими друг друга слоями и прослоями мергелей, мергель-гипсовой породы.

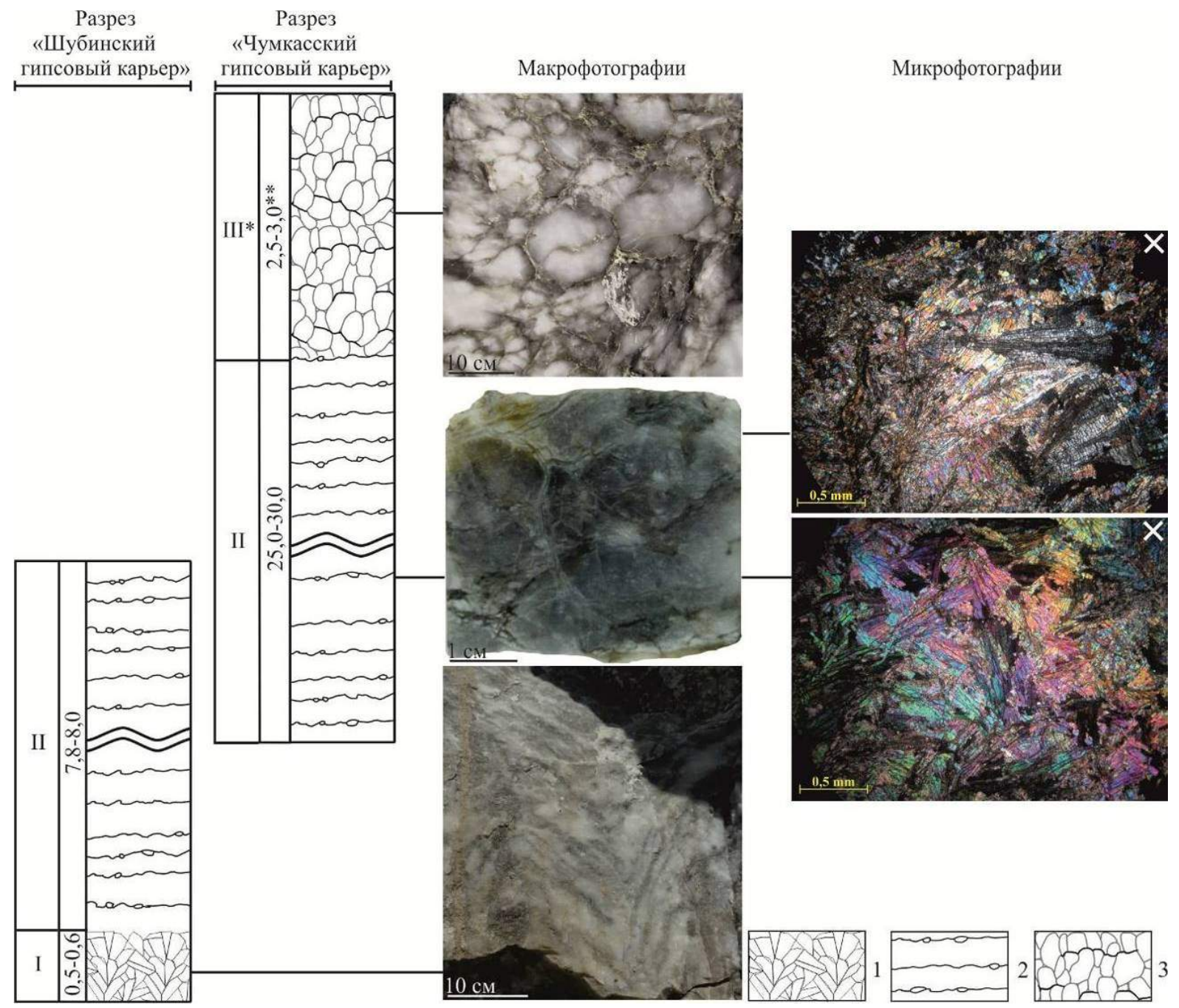

Рис. 9. Литологический разрез лунежской пачки. Сульфаты: 1 - с реликтовым шевронным строением; 2 -массивные; 3 -желваковые 


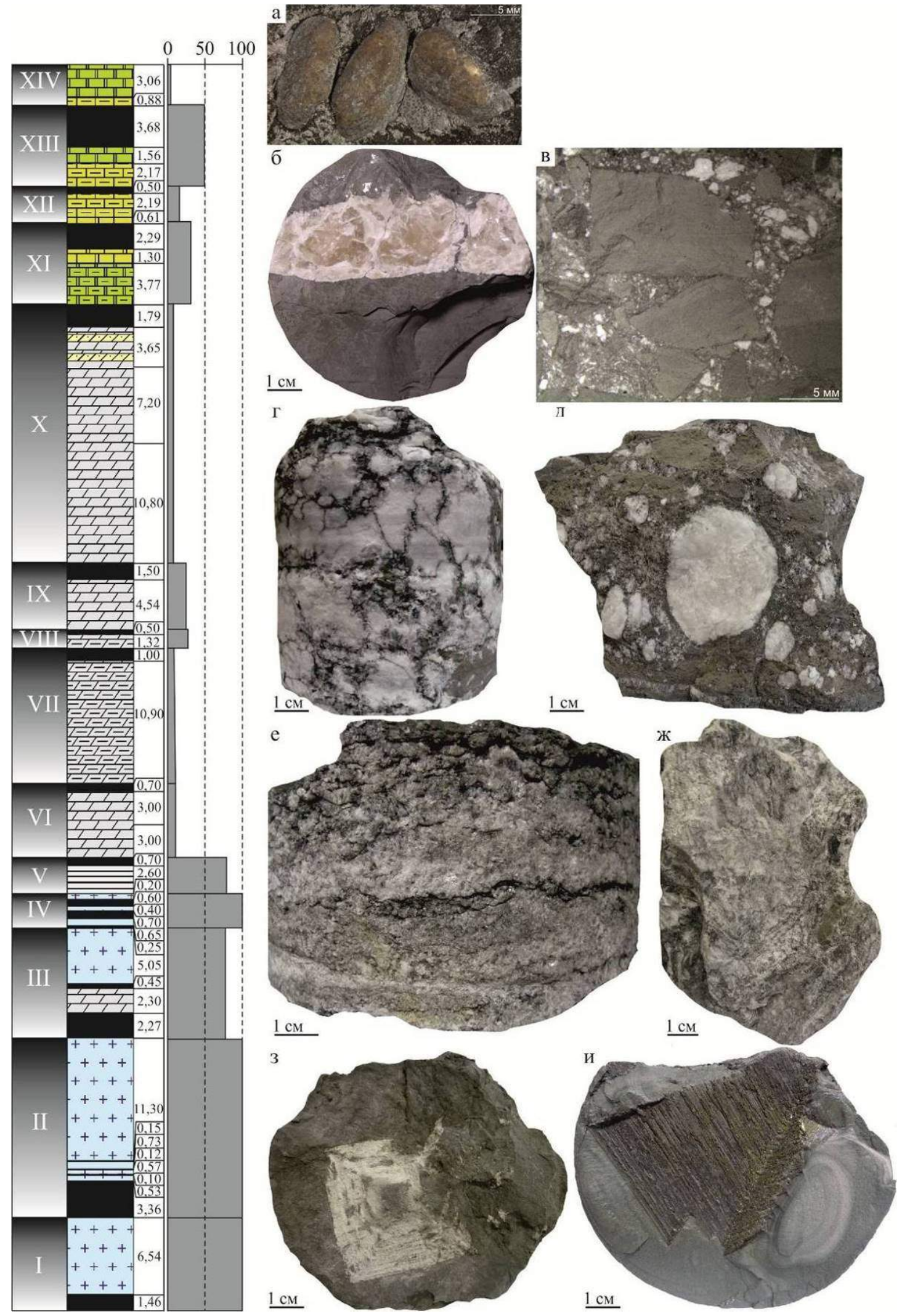

Рис. 10. Литологический разрез соликамской свиты надсолевой толщи Верхнекамского месторождения по скв. 704/1 (Половодовский участок): a-раковины двустворок; б-е - желваки гипса (б - в секущих трещинах; в - в составе цемента брекчии; г-д-прослои); е-массивный прослой гипса; ж-прослой гипса с "теневым" шевронным строением; з, и-псевдоморфозы по "лодочкам" галита 
В нижней части толщи иногда присутствуют маломощные прослои каменной соли. В разрезе соляно-мергельной толщи Половодовского участка Верхнекамского месторождения (рис. 10), расположенного в центральной части Соликамской впадины, нами выделены тринадцать ритмопачек. В основании нижних четырех пачек лежит мергель-гипсовая порода, сменяющаяся выше по разрезу каменной солью, а верхние пачки (5-13) начинаются с терригенно-карбонатных разностей и завершаются существенно сульфатной породой. Заканчивается разрез тонкослоистыми доломитами. По распределению эвапоритовых пород в соляно-мергельной толще и их доле в общем объеме ритмопачки можно выделить три периода усиления эвапоритового режима бассейна осадконакопления: наиболее мощный в начальный период накопления толщи (1-5 ритмопачки) и два менее интенсивных в середине и на завершающих стадиях (8-9 и 11-13 ритмопачки соответственно).

Мергели обычно пелитоморфные тонкослоистой до массивной текстуры; состав их карбонатной составляющей варьируется от существенно известковой до существенно доломитовой. В верхней части соляно-мергельной толщи нередко отмечаются полиминеральные псевдоморфозы по раковинам двустворок [16], а в нижней - пирит-кальцит-кварц-халцедоновые псевдоморфозы по скелетным кристаллам ("лодочкам") галита. Гипс (редко ангидрит) встречается на разных глубинах, где слагает желваки $(0,5-10 \mathrm{~cm}$, реже больше) и их прослои. Отмечено, что форма желваков разная: в прослоях они, как правило, вытянуты по вертикали, нередко каплеобразные (расширяются от основания к вершине), тогда как одиночные обособления - изометричные, округлые. Кроме того, желваки гипса отмечены в виде цепочек, приуроченных к секущим трещинам, и в составе цемента некоторых (литогенетических?) брекчий. Изредка гипс слагает маломощные (до 50 см) прослои, на фоне массивной текстуры которых иногда фиксируется «теневое» шев- ронное строение. В целом для отложений соляно-мергельной толщи характерна сильная фациальная изменчивость как по вертикали, так и латерали - прослои не выдержаны по мощности, нередко выклиниваются [7].

В пределах Чумкасского гипсового месторождения и в разрезе "Чусовская стрелка" соликамские отложения залегают на лунежских сульфатах со стратиграфическим перерывом (рис. 11).

В нижней части свита представлена светло-серым пелитоморфным доломитом со средне-, тонкослоистой мелко-, крупноволнистой текстурой (слой 1). Изредка встречаются линзочки оолитового сложения. На поверхности прослоев доломита иногда наблюдаются отпечатки скелетных кристаллов галита и льда, а также концентрические полигональные трещины усыхания. В пределах слоя фиксируются множественные строматолитовые постройки, среди которых наиболее распространены очень крупные (диаметр более 1 м) полушаровидной формы, реже встречаются волнисто-слоистые пластовые, столбчатые [13, 17].

Выше следует гипсовая порода (2-5 слои). В основании залегает слой мелко-, среднезернистого гипса с реликтовым шевронным строением (слой 2). Морфология "двойников" разнообразна: отмечаются слои веерообразных кристаллов, остро- и широкоугольные кристаллические сростки. Краевые части былых индивидов насыщены глинисто-карбонатным материалом. Выше по разрезу "двойники" перекрыты ритмично-слоистой мелко-, микрозернистой гипсовой породой (слой $3)$, в кровле прослоев которой иногда отмечаются глинисто-карбонатные слойки мощностью до первых миллиметров. Выше по разрезу количество глинистокарбонатного материала в породе увеличивается (до 15-20\%) и гипсовая порода приобретает желваковую (слой 4) и линзовидно-желваковую (слой 5) текстуру. Желваки гипса преимущественно округлые с заливообразными границами, их размер варьируется от нескольких 


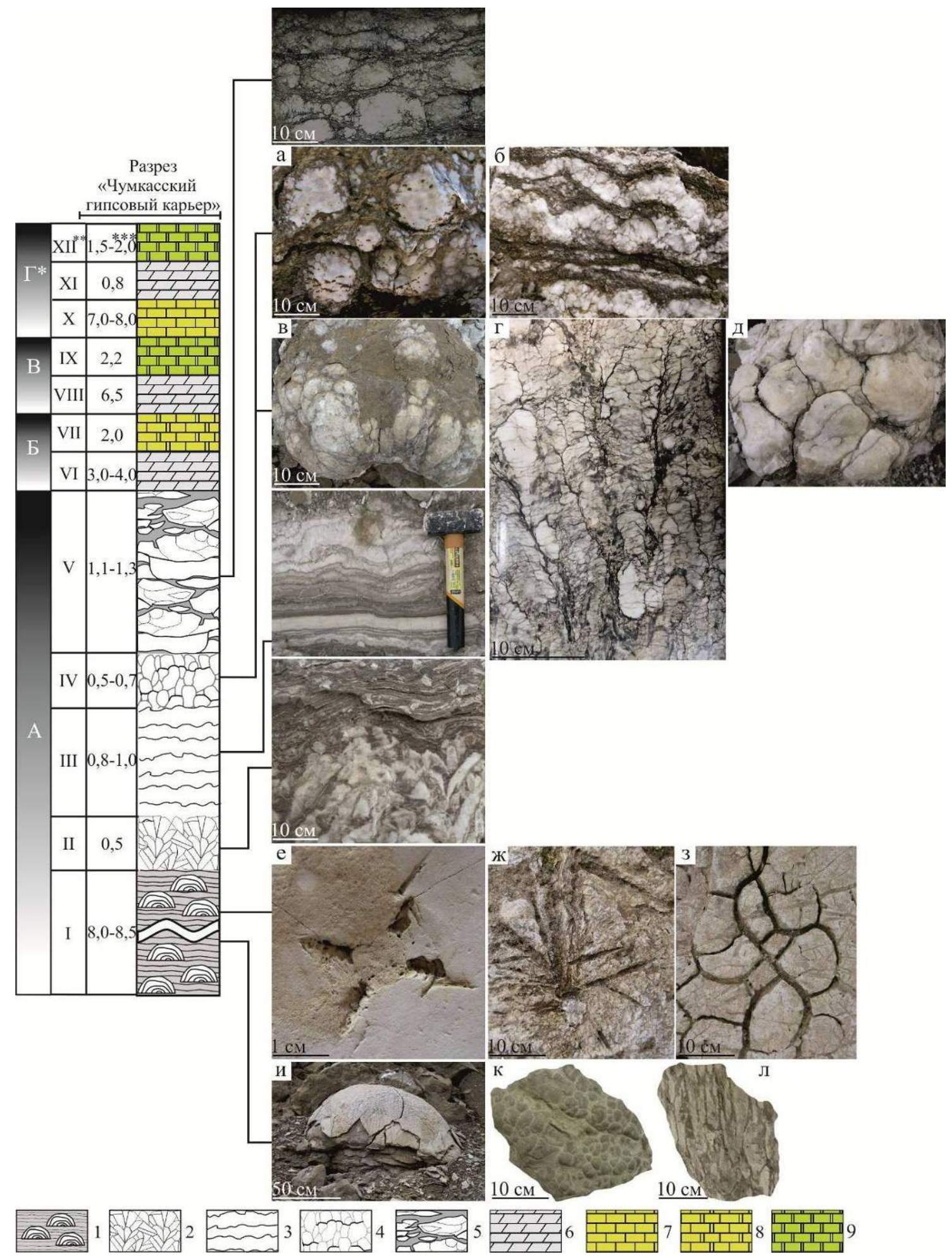

Рис. 11. Литологический разрез соликамской свиты на Чумкасском гипсовом карьере: 1 - тонкослоистый доломит со строматолитовыми постройками; 2-5 - текстурно-структурные типы сульфатов (2 - с реликтовым шевронным строением; 3 - неяснослоистые; 4 - желваковые; 5 -линзовидно-желваковые); 6 - мергель; 7 - известняк; 8 -известняк доломитовый; 9 доломит. Обозначения: $а$-желваки гипса; $\sigma$ - энтеролитовая складчатость; в-д - агрегаты желваков гипса типа "иветной капусты" (в, г - продольный срез; д - поперечный); е - отпечаток скелетного кристалла каменной соли; ж - отпечатки кристаллов льда; з - трещины усыхания; и-л - строматолитовые постройки (и - полушаровидные; к - волнисто-слоистые пластовые; л-столбчатые) 
миллиметров до 10-15 см. Иногда в основании прослоев они формируют агрегаты типа "цветной капусты". В поперечном срезе такой агрегат характеризуется полигональным строением, а в продольном видно, что слагающие его желваки имеют каплевидную форму (расширяются от основания к кровле). Отмечено, что на отдельных редких участках прослои желваков ангидрита смяты (т.н. энтеролитовая складчатость).

Слои 6-12 сложены глинистокарбонатными разностями, состав карбонатной составляющей которых варьируется от известковистого до доломитового. Породы характеризуются пелитоморфной структурой и тонкослоистой текстурой, нередко тонкой плитчатой отдельностью.

Таким образом, разрез соликамской свиты Чумкасского гипсового карьера, как и разрез соляно-мергельной толщи Верхнекамского месторождения, характеризуется ритмичностью.

\section{Обсуждение результатов и заключение}

Изучение структурно-вещественных особенностей филипповско-иренских эвапоритов показало, что для сульфатных пачек в целом характерно циклическое строение. В подошве прослоев в большинстве случаев отмечаются шевронные структуры, которые выше по разрезу постепенно сменяются мелкозернистой неяснослоистой (центр), а затем желваковой и/или линзовидно-желваковой (кровля) породой. Такое текстурно-вещественное строение прослоев позволяет предполагать, что садка сульфатного вещества началась с образования крупных кристаллов гипса и их двойниковых агрегатов из слабонасыщенных растворов [40]. Их смена вверх по разрезу мелкозернистым материалом свидетельствует о последующем пересыщении рассолов в бассейне осадконакопления и массовом отложении пелитоморфного гипсового [31] или бассанитового [29, 38] материала. Изменение массивной текстуры сульфатов на линзовидножелваковую и желваковую обусловлено увеличением содержания в породе глинисто-карбонатной составляющей [9]. Последнее может свидетельствовать об опреснении палеобассейна и привносе терригенных осадков. Таким образом, наблюдаемая смена шевронного гипса неяснослоистым, желваковым и линзовидножелваковым представляет собой результат закономерного изменения состава вод бассейна на сульфатной стадии цикла (ритма).

В работах многих исследователей показано, что образование желваков происходит на стадии диагенеза за счет собирательной перекристаллизации в илистом глинисто-карбонатно-сульфатном материале. Однако дискуссионным до сих пор является вопрос об образовании желваков сульфатов с вытянутой формой. Одни исследователи $[23,36]$ считают, что они являются своеобразными псевдоморфозами по первичным шевронным кристаллам гипса, от которых наследуют вертикальную ориентировку и вытянутую форму. Другие [15, 28, 35] связывают их формирование с тектоническими (пластическими) деформациями. В некоторых работах $[32,35]$ линзовидная и линзовидножелваковая форма сульфатных обособлений объясняется преобразованием (растворением) осадка под действием литостатического давления.

Наши наблюдения показывают, что морфология желваков определяется количеством сульфатного материала, а также анизотропией минералообразующей среды. Так, в глинисто-карбонатной «матрице» растущие единичные желваки, получающие равномерное питание со всех сторон и не ограниченные в пространстве, характеризуются существенно сферической формой (рис. 10,д, 11,a). В случае незначительного количества несульфатного материала многочисленные желваки имеют форму воздушного шара и растут в направлении обогащенной водой кровли слоя - вплоть до параллельношестоватого агрегата (рис. 10,г, 11,в, г). Такое явление получило название геометрического отбора [4]. В ярко выраженной 
слоистой среде желваки имеют форму линз, что может являться результатом соответствующей симметрии питающей среды, определяемой законом Кюри [20]. Послойное разрастание желваков приводит к формированию второй генерации кристаллов ангидрита, ориентированных вдоль их поверхности (рис. 3, 7, 9).

Природа энтеролитовой складчатости в сульфатных отложениях давно обсуждается. Многие связывают ее с процессами гидратации, когда при увеличении объема породы отдельные прослои сминаются в складки $[1,14,21,42]$. Однако исследования современных себх показали, что желваковые и энтеролитовые структуры встречаются уже на глубине 1-2 м выше уровня грунтовых вод (зона капиллярного поднятия) и сложены нелитифицированным ангидритом [24, 27]. Это обстоятельство дало основание предполагать их формирование в процессе роста на стадии раннего диагенеза как желваков, так и сминающихся слоев ангидрита, а не при гидратации на стадии гипергенеза $[26,27$, $30,33,34,43]$.

Закономерностей изменения текстур карбонатных пачек по разрезу не выявлено. Они характеризуются выдержанным тонкослоистым пелитоморфным, реже массивным оолитовым, строением, и лишь в краевых частях прослоев отмечаются небольшие линзовидно-желваковые обособления гипса. Переслаивание пелитоморфного и оолитового доломита может говорить о периодичном обмелении бассейна осадконакопления и смене тонкодисперсного материала оолитовым, характерным для зоны активной волновой деятельности. Присутствие в центре многих оолитов пустот, а также наличие интерстициального кальцита в доломитовых оторочках позволяют предполагать, что в качестве их затравки выступал пелитоморфный известковый материал, который в дальнейшем был выщелочен.

Появление участков оолитового строения с поровым пойкилитовым гипсовым цементом, а также присутствие желваков сульфатов в секущих трещинах позволяют предполагать, что часть сульфата в карбонатных пачках имеет не седиментационную природу, а связана с привносом сульфат-иона на стадии диагенеза. Присутствие строматолитовых построек говорит о мелководных условиях образования карбонатов $[11,17]$. Наличие в них зоны окремнения, вероятно, свидетельствует об изменении условий в палеобассейне, приведших к вымиранию организмов и разложению органического вещества, формированию кислых условий, благоприятных для осаждения кремнезема. Присутствие отпечатков и псевдоморфоз по скелетным кристаллам галита в терригеннокарбонатных породах соликамской свиты свидетельствует о повышенной солености вод бассейна, приближающейся к галитовой садке, которая начинается при минерализации воды 300-325 г/л [5].

Таким образом, выявленные вещественно-структурные особенности карбонатных и сульфатных пород позволили проследить эволюцию осадконакопления в пределах каждого ритма и составить для них типовой идеализированный разрез (рис. 12,IV).

Схожая последовательность изменения структурно-вещественных характеристик карбонатно-сульфатных эвапоритов отмечается в разрезе мессиния (верхний миоцен) Северных Апеннин (рис. 12,II) [37]. Осадочный цикл здесь начинается с тонкослоистых аргиллитов, известняков и строматолитовых доломитов. Гипсовая часть разреза представлена шевронной разностью, которая перекрыта неяснослоистой. Однако верхняя часть разреза осложнена хаотическими гипсовыми отложениями, которые связываются с оползневыми потоками. Такая последовательность отвечает условиям мелководий краевых частей высыхающего бассейна либо соляных озер, расположенных близко к морю $[37,39]$.

Некоторое сходство отмечено в строении формации Канган (нижний триас) Персидского залива (рис. 12,III) [43]. В основании цикла здесь залегают массивные до слоистых известковистые аргилли- 
ты, глинистые карбонаты и органогеннодетритовые доломиты. Сульфаты представлены массивной породой, которая в верхней части разреза постепенно сменяется желваковой. В отличие от карбонатно-сульфатного разреза нижнепермских эвапоритов циклы в формации Канган не выдержаны и в редких случаях их мощность превышает первые метры. Предполагается [43], что формирование пород здесь происходило в субаквальных мелководных условиях, которые на завершающей стадии сменились субаэральными (условия себх).

Близкие черты строения характерны также для осадочного цикла современных солончаков Южной Австралии (оз. Марион, Нью-Лейк, Мак-Доннелл), где в осно- вании залегают крупные сдвойникованные кристаллы гипса, перекрываемые выше по разрезу тонкослоистым мелкозернистым гипсом [22].

В отличие от субаквальных отложений карбонатно-сульфатные породы себхи не показывают четко выраженного циклического строения. Примером современной себхи с карбонатным осадконакоплением является район Абу-Даби на берегу Персидского залива (рис. 12,I) [22]. Здесь осадочный цикл начинается с лагунных и карбонатных песков и/или илов, в кровле которых залегают небольшие водорослевые маты и строматолиты. Выше по разрезу поровые воды характеризуются более высокой минерализацией,

чTо
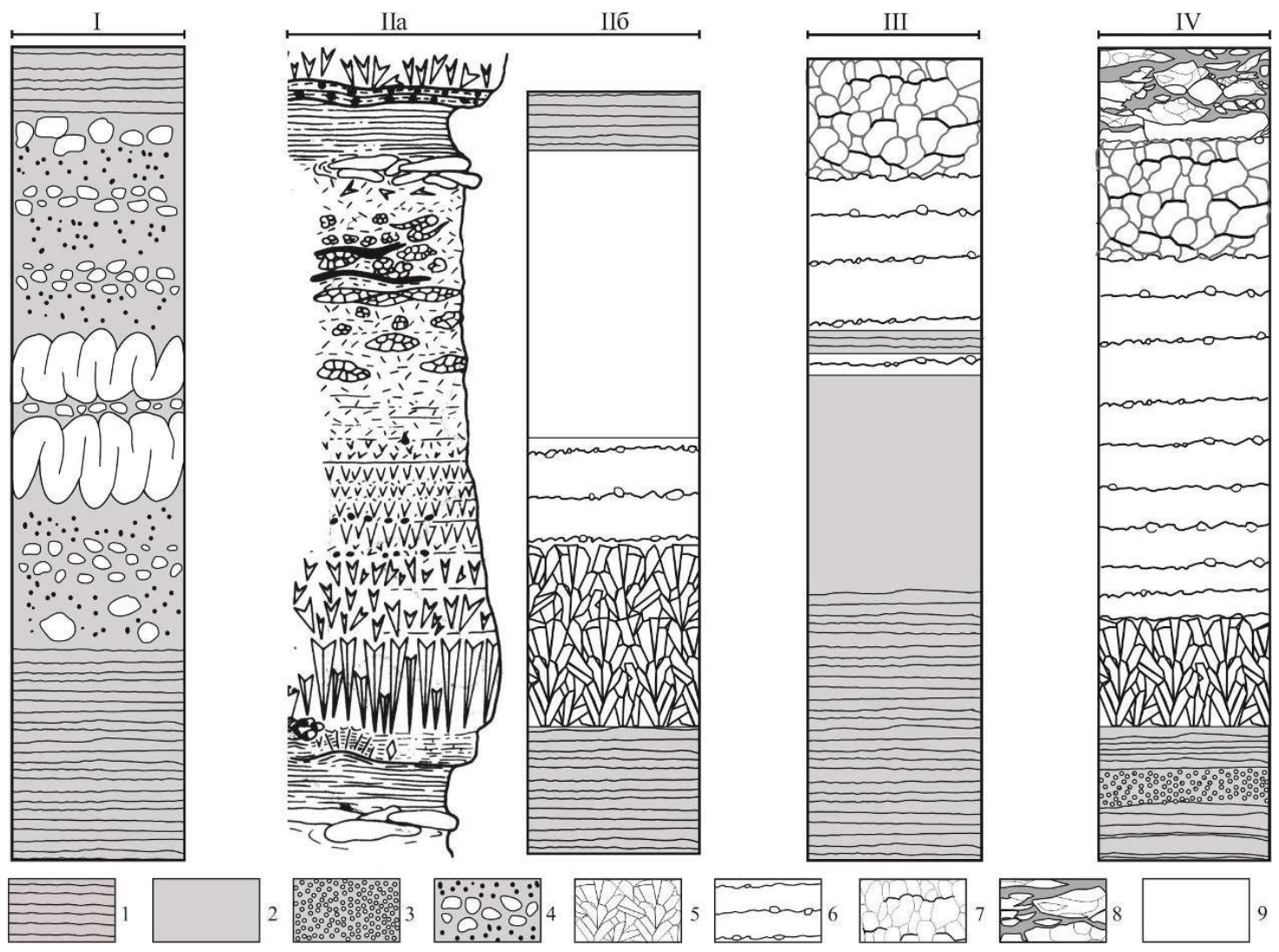

Рис. 12. Сопоставление схематизированных разрезов себхи (I) и осадочных циклов мессиния Северных Апеннин (IIa - nо [Vai, Ricci-Lucchi, 1977]; IIб - стилизированный), нижнего триаса формации Канган Персидского залива (III) и нижнепермских карбонатно-сульфатных эвапоритов Пермского Прикамья (IV): 1-4 - структурно-текстурные типы карбонатов (1 - тонкослоистые пелитоморфные; 2 - органогенно-детритовые; 3 - массивныле оолитовые; 4 массивные с рассеянными желваками); 5-9 - структурно-текстурные типы сульфатов (5 - с реликтовым шевронным строением; 6 - массивные; 7 - желваковые; 8 - линзовидножелваковые; 9 -хаотические) 
способствует интенсивному росту гипсовых кристаллов и формированию прослоев (до $30 \mathrm{~cm}$ ), представляющих собой "кашу" мелких зерен. В процессе диагенеза такая "каша" не только дегидратируется, но и превращается в складчатые и энтеролитовые слои. В средней части себхи за счет повышенного испарения увеличивается минерализация поровых вод, что провоцирует осаждение эфемерного галита и дегидратацию гипса с образованием массивного и желвакового ангидрита. Завершается разрез материалом ветровых наносов, в котором благодаря поступлению с грунтовыми водами сульфат-иона образуются ангидритовые или гипсовые кристаллы. Галит в этой зоне осаждается локально в виде корковых кристаллов и цемента.

Схожая последовательность фаций отмечается и в древних себхах, примером одной из которых является разрез нижнего пурбека (верхняя юра) Южной Англии [34]. В отличие от себхи побережья Персидского залива здесь отсутствуют карбонатные илы и присутствуют горизонты ископаемых почв, что может говорить о формировании отложений пурбека в менее аридных условиях $[25,41]$.

Таким образом, переслаивание карбонатных и сульфатных пачек в разрезе кунгурских эвапоритов Пермского Прикамья свидетельствует о проявлении пяти циклов развития эвапоритового бассейна, которое завершилось его полным усыханием (исключение составила территория Соликамской впадины). Соликамские соляномергельные отложения сформировались в начальный период последнего трансгрессивного цикла раннепермского моря, когда шло постепенное распреснение реликтовой кунгурской лагуны в условиях, близких к современным себхам. Смена тонкослоистого пелитоморфного или массивного оолитового доломита шевронной, массивной, желваковой и линзовидножелваковой сульфатной породой в пределах ритмопачки отражает закономерное изменение состава вод бассейна в течение одного цикла. Выдержанное строение ритмопачек и их неоднократное чередование в разрезе нижнепермских эвапоритов говорят об осадконакоплении в обширном мелководном, периодически опресняющемся бассейне. Текстура сульфатов формируется на стадии седиментации и диагенеза и зависит от содержания несульфатного материала в породе и анизотропии минералообразующей среды.

\section{Библиографический список}

1. Вассоевич Н.Б. Текстура осадочных горных пород // Справочное руководство по петрографии осадочных пород. Л.: ГНТИ нефтяной и горно-топливной литературы, 1958. T. I. C. $95-12$.

2. Герасимов Н.П. Кунгурский ярус Камского Приуралья // Учен.зап. Перм. ун-та, 1952. Т. 7, вып. 1. С. 3-38.

3. Герасимов Н.П. О циклах осадконакопления в верхнем палеозое Пермского Приуралья и о границе карбона и перми // Международный геологический конгресс. XVII сессия: тез. докл. М; Л.: ОНТИ, 1937. C. 87-88.

4. Григорьев Д.П., Жабин А.Г. Онтогения минералов. М.: Наука, 1975. 340 с.

5. Жеребиова И.К., Волкова Н.Н. Экспериментальное изучение поведения микроэлементов в процессе естественного солнечного испарения воды Черного моря и рапы Сасык-Сивашского озера // Геохимия. 1966. № 7. С. 832-845.

6. Золотова В.П. Верхний горизонт кунгурского яруса Пермского Прикамья // Учен. зап. Перм. ун-та. 1961. Т. 18, вып. 2. С. 313.

7. Иванов А.А., Воронова М.Л. Верхнекамское месторождение калийных солей. Л.: Недра, 1975. 219 с.

8. Игнатьев В.И. Формирование ВолгоУральской антеклизы в пермский период. Казань: Изд-во Казан. ун-та, 1976. 256 с.

9. Копнин В.И. Кальциево-сульфатные породы в пермских отложениях Пермского Приуралья // Моделирование геол. систем и процессов: мат-лы регион. конф./ Перм. гос. ун-т. Пермь. 1996. С. 130-132.

10. Копнин В.И. Условия седиментации кунгурских соленосных отложений в Соликамской впадине Предуральского прогиба // Труды ВНИГНИ (Камское отделение). 
Пермь: Перм. книж. изд-во, 1973. Вып. 118. C. 221-238.

11. Маслов В.П. Строматолиты // Труды ГИН АН СССР. 1960. Вып. 41. 188 с.

12. Международный конгресс «Пермская система земного шара». Путевод. геологических экскурсий / под ред. Б.И. Чувашова; УрО РАН. Свердловск, 1991. 153 с.

13. Hаугольных С.В. Стратотип кунгурского яруса и его корреляционный потенциал // Биота Востока Европейской России на рубеже ранней и поздней перми: мат-лы к Междунар.симп. «Верхнепермские стратотипы Поволжья». М.: ГЕОС, 1998. С. 1933.

14. Ованесов Г.П., Алексеев Г.П., Белоликов Н.И. $и$ др. Геологическая эффективность геофизических работ в Волго-Уральской нефтегазоносной провинции. М.: Недра, 1980. $253 \mathrm{c}$.

15. Петротектонические основы безопасной эксплуатации Верхнекамского месторождения калийно-магниевых солей/ под ред. Н. М. Джиноридзе. СПб.; Соликамск, 2000. $400 \mathrm{c}$.

16. Силантьев В.В. Уфимский ярус. Соликамский горизонт //Биота Востока Европейской России на рубеже ранней и поздней перми: мат-лы к Междунар. симп. «Верхнепермские стратотипы Поволжья». М.: ГЕОС, 1998. С. 37-54.

17. Сонин Г.В., Калинина Т.А., Осин Ю.Н., Воробъев В.В. Стеночные строматолиты соликамского горизонта Пермского Приуралья и их происхождение // Современные концепции научных исследований: мат-лы XII Междунар. конф. М., 2015. С. 141-147.

18. Софроницкий П.А., Золотова В.П. Нижний горизонт кунгурского яруса Пермского Прикамья // Учен. зап. Перм. ун-та. 1957. Т. 11, вып.2. С. 5-12.

19. Чувашов Б.И., Черных В.В. Филипповский карьер // Геологические памятники Пермского края: энциклопедия/ Горный институт УрО РАН. Пермь: Книжная площадь, 2009. C. 123-128.

20. Шафрановский И.И. Внешняя симметрия реальных кристаллов и симметрия питающей среды // Зап. Всесоюз. мин. об-ва. 1954. Ч. 83, № 3.

21. Швещов М.С. Петрография осадочных пород. М.: Госгеолтехиздат, 1958. 417 с.

22. Шрейбер Б.Ш., Такер М.Е., Тилла Р. Побережья аридных зон и эвапориты // Об- становки осадконакопления и фации: в 2 т. М.: Мир, 1990. Т.1. С. 232-279.

23. Bossio A., Esteban M., Giannelli L., Longinelli A., Mazzanti R., Mazzei R., Ricci Lucchi $F$., Salvatorini G. Some aspects of the upper Miocene in Tuscany // Messinian Seminar. Pisa, 1978. $88 \mathrm{p}$.

24. Evans G., Kirkham A. The Quaternary deposits // The emirates: a natural history/ P. Hellyer, G. Aspinall. London: The Trident, 2005. P. 65-79.

25. Francis J.E. The dominant conifer of the Jurassic Purbec Formation, England // Palaeontology. 1983. № 26. P. 277-294.

26. Holliday D.W. Nodular gypsum and anhydrite rocks in the Billefjordan region, Spitsbergen // Nor. Polarinst. 1965. P. 65-73.

27. Hussain M., Warren J.K. Nodular and enterolithic gypsum: the "Sabkha-tization" of Salt flat playa, West Texas // Sedimentary geology. 1989. Vol. 64. P. 13-24.

28. Kasprzyk A., Orti F. Paleogeographic and burial controls on anhydrite genesis: a case study from the Badenian basin in the Carpathian Foredeep (southern Poland, western Ukraine) // Sedimentology. 1998. № 45. P. 889-907.

29. Kinsman B. Wind Waves. Englewood Cliffs, New Jersey: Prentice Hall, 1965. 676 p.

30. Lugli S., Gennari R., Gvirtzman Z., Manzi V., Roveri M., Schreiber C.B. Evidence of clastic evaporites in the canyons of the Levant Basin (Israel): implication for the Messinian salinity crisis // Journal of sedimentary research. 2013. Vol. 83. P. 942-954.

31. Macdonald G.S. Anhydrite-gypsum equilibrium relationships // American Journal of Science. 1953. № 251 (12). P. 884-898.

32. Nanfito $F$. Timing of Diagenesis and Deformation of Carboniferous Gypsum \& Anhydrites in Spitsbergen/ In Partial fulfillment of the requirements for the Degree. Summer, 2008. $62 \mathrm{p}$.

33. Orti F., Rosell L., Ingles M., Playa E. Depositional models of lacustrine evaporites in the SE margin of the Ebro Basin (Paleogene, NE Spain) // Geologica Acta. 2007. Vol. 5, № 1. P. 19-34.

34. Shearman D.J. Origin of marine evaporites by diagenesis // Transactions of The Institution of Mining and Metallurgy. 1966. № 75. P. 208-215.

35. Shearman D.J. Syndepositional and late diagenetic alteration of primary gypsum to anhydrite // Sixth International Symposium on 
Salt. Alexandria: Salt Institute, 1985. Vol. 1. P. 41-50.

36. Testa G., Barbieri M., Cortecci G. The origin of Messinian evaporites from Tuscany (Italy) based on new stratigraphic and Geochemical data // 17th Regional African European Meeting of Sedimentology: abstract volume. SfaxTunisia, 1996. P. 264-265.

37. Vai G.R., Ricci-Lucchi F. Algal crusts autochthonous and clastic gypsum in a cannibalistic evaporite basin: a case history from the Messinian of the Northen Apennines // Sedimentology. 1977. № 24. P. 211-244.

38. Van Driessche A.E.S. Benning L.G., Rodriguez-Blanco J.D. et al. The role and implications of bassanite as a stable precursor phase to gypsum precipitation // Science. 2012. Vol. 336 (6077). P. 69-72.

39. Warren J.K. On pedogenic calcrete as it occurs in the vadose zone of Quaternary calcareous dunes in Coastal South Australia //
Journal of Sedimentary Petrology. 1983. № 29. P. 609-638.

40. Warren J.K. The hydrological setting, occurence and significance of gypsum in late Quaternary salt lakes in South Australia // Sedimentology. 1982. № 29. P. 609-638.

41. West I.M. Evaporites and associated sediments of the basal Purbec formation (upper Jurassic) of Dorser // Proceedings of The Geologists Association. 1975. № 86. P. 205253.

42. West I.W. Review of evaporite diagenesis in the Purbek Formation of Southern England // Symposium Sedimentation jurassique W. Europeen. 1979. № 1. P. 407-416.

43. Zamannejad A., Jahani D., Lotfpour M., Movahed $B$. Mixed evaporite/carbonate characteristics of the Triassic Kangan Formation, offshore area, Persian Gulf/// Revista Mexicana de Ciencias Geológicas. 2013. Vol. 30, № 3. P. 540-551.

\section{Lithology of Lower Permian Carbonate and Sulfate Evaporites at the Area of a «Classical» Kungurian sediments: Perm kray}

\section{T.A. Kalinina}

Mining Institute of Ural Branch of Russian Academy of Science. 78A Sibirskaya Str., Perm 614007, Russia. E-mail: tatyanaak89@mail.ru

Lithological study of carbonate and sulfate evaporites of the "classical" Kungur sediments (Perm kray) allowed identifying that these strata were created during the five formation cycles of the evaporate basin finalized with its shrinkage (except the territory of the Solikamsk basin). Replacement of thin-bedded pelitomorphic or massive oolitic dolomite by chevron, massive and nodular sulfates within a cyclothem may indicate the regular variation of basin water concentration during a cycle. This cyclothems structure and their numerous alternations in cross-section of Lower Permian evaporites are indicators of sedimentation in the widespread shallow, periodically freshened basin. Sulfates texture is formed at a sedimentation-and-diagenesis stage and depends on the content of not-sulfate materials in the rock and anisotropy of the minerogenesis environment. Lithologic features of younger Solikamsk rocks formed after chlorides in the Solikamsk basin allow supposing that their formation conditions were close to modern sabkha.

Key words: Perm region, carbonate and sulfate evaporites, lithology, Irenskaya Suite, Kungur.

\section{References}

1. Vassoevich N.B. 1958. Tekstura osadochnykh gornykh porod [Texture of sedimentary rocks]. In Spravochnoe rukovodstvo po petrografii osadochnykh porod. T. I. GNTI nef-

tyanoj i gorno-toplivnoj literatury. Leningrad, pp. 95-12. (in Russian)

2. Gerasimov N.P. 1952. Kungurskiy yarus Kamskogo Priuralya [Kungurian Stage of the 
Kama Pre-Urals]. Uch. zap. Perm. Univ., 7(1): 3-38. (in Russian)

3. Gerasimov N.P. 1937. O tsiklakh osadkonakopleniya $\mathrm{v}$ verkhnem paleozoe Permskogo Priuralya i o granitse karbona i permi [About sedimentation cycles in the Upper Paleozoic of Perm Pre-Urals and about boundary between Carboniferous and Permian Systems]. In Mezhdunarodnyy geologicheskiy kongress. XVII sessiya: Tez. dokl. MoskvaLeningrad, ONTI, pp. 87-88. (in Russian)

4. Grigoriev D.P., Zhabin A.G. 1975. Ontogeniya mineralov [Ontogeny of minerals]. Nauka, Moskva, p. 340. (in Russian)

5. Zherebtsova I.K., Volkova N.N. 1966. Eksperimentalnoe izuchenie povedeniya mikroelementov $\mathrm{v}$ protsesse estestvennogo solnechnogo ispareniya vody Chernogo morya $\mathrm{i}$ rapy Sasyk-Sivashskogo ozera [Experimental studies of behavior of trace elements during evaporation of the Black Sea water and the Sasyk-Sivashsk lake brine]. Geokhimiya. 7: 832-845. (in Russian)

6. Zolotova V.P. 1961. Verkhniy gorizont kungurskogo yarusa Permskogo Prikamya [The Upper horizon of Kungurian Stage of the Perm Pre-Kama]. Uch. zap. Perm. Un-ta. 18(2): 3-13. (in Russian)

7. Ivanov A.A., Voronova M.L. 1975. Verkhnekamskoe mestorozhdenie kaliynykh soley [Verhnekamskoe salt deposit]. Nedra, Leningrad, p. 219. (in Russian)

8. Ignatiev V.I. 1976. Formirovanie VolgoUralskoy anteklizy v permskiy period [Formation of the Volga-Uralian anticlyse during Permian period]. Izd-vo Kazansk. Univ, Kazan, p. 256. (in Russian)

9. Kopnin V.I. 1996. Kaltsievo-sulfatnye porody v permskikh otlozheniyakh Permskogo Priuralya [Calcium sulfate rocks in Permian deposits of the Perm Pre-Urals]. In Modelirovanie geol. sistem i protsessov. Mat. region. konf. Perm. Univ, Perm, pp. 130-132. (in Russian)

10. Kopnin V.I. 1973. Usloviya sedimentatsii kungurskikh solenosnykh otlozheniy v Solikamskoy vpadine Preduralskogo progiba [Sedimentation conditions of the Kungurian saliferous deposits in the Solikamsk basin of the Pre-Urals depression]. In Trudy VNIGNI (Kamskoe otdelenie). Perm. knizh. izd-vo, Perm, 118: 221-238. (in Russian)

11. Maslov V.P. 1960. Stromatolity [Stromatolites]. In Trudy GIN AN SSSR. V. 41, p. 188. (in Russian)
12. Mezhdunarodnyy kongress «Permskaya sistema zemnogo shara» [International congress "Perm System of the Earth"]. Putevod. geologicheskikh ehkskursiy. Ed. B.I. Chuvashova. UrO RAN, Sverdlovsk, 1991, p. 153. (in Russian)

13. Naugolnykh S.V. 1998. Stratotip kungurskogo yarusa i ego korrelyatsionnyy potentsial [Stratotype of Kungurian Stage and its correlation potential]. In Biota Vostoka Evrop. Rossii na rubezhe ranney i pozdney permi. Mat. k Mezhdunar. simp. "Verkhnepermskie stratotipy Povolzhya". GEOS, Moskva, pp. 19-33. (in Russian)

14. Ovanesov G.P., Alekseev G.P., Belolikov N.I. et al. 1980. Geologicheskaya effektivnost geofizicheskikh rabot $\mathrm{v}$ Volgo-Uralskoy neftegazonosnoy provintsii [Geological effectiveness of geophysical prospecting in the Volga-Uralian oil-and-gas province]. Nedra, Moskva, p. 253. (in Russian)

15. Petrotektonicheskie osnovy bezopasnoy ekspluatatsii Verkhnekamskogo mestorozhdeniya kaliyno-magnievykh soley [Petrotectonic fundamentals of safe mining operation in the Upper Kama deposit of potashmagnesium salts]. $E d$. Dzhinoridze N.M. OGUP «Solikamsk», SPb-Solikamsk, 2000, p. 400. (in Russian)

16. Silantyev V.V. 1998. Ufimskiy yarus. Solikamskiy gorizont [Ufimian Stage. Solikamsk Horizon]. In Biota Vostoka Evropejskoy Rossii na rubezhe ranney i pozdney permi. Mat. k Mezhdunar. Simp. "Verkhnepermskie stratotipy Povolzhya". GEOS, Moskva, pp. 37-54. (in Russian)

17. Sonin G.V., Kalinina T.A., Osin Yu.N., Vorobev V.V. 2015. Stenochnye stromatolity solikamskogo gorizonta Permskogo Priuralya i ikh proiskhozhdenie ["Stenochnye" stromatolites of the Solikamsk horizon of the Perm Pre-Urals and their origin]. In Sovremennye kontseptsii nauchnykh issledovaniy. Mat. XII Mezhdunar. konf. Moskva, pp.141-147. (in Russian)

18. Sofronitskiy P.A., Zolotova V.P. 1957. Nizhniy gorizont kungurskogo yarusa Permskogo Prikamya [The lower horizon of Kungurian Stage of the Perm Pre-Kama]. Uch. zap. Perm. Univ., 11(2): 5-12. (in Russian)

19. Chuvashov B.I., Chernykh V.V. 2009. Filippovskiy karier [Filippovsky open-pit quarry]. In Geologicheskie pamyatniki Permskogo kraya: Entsiklopediya. Gornyy Institut UrO 
RAN, Knizhnaya ploshzhad, Perm, pp. 123128. (in Russian)

20. Shafranovskiy I.I. 1954. Vneshnyaya simmetriya realnykh kristallov i simmetriya pitayushzhej sredy [External symmetry of real crystals and symmetry of the source environment]. Zapiski Vses. min. ob-va. 83(3). (in Russian)

21. Shvetsov M.S. 1958. Petrografiya osadochnykh porod [Petrography of sedimentary rocks]. Gosgeoltekhizdat, Moskva, p. 417. (in Russian)

22. Schreiber B.C., Tucker M.E., Till R. 1986. Arid shorelines and evaporites. In Reading H.G. (Ed.) Sedimentary Environments and Facies. Blackwell Scientific, Oxford, pp. 189228.

23. Bossio A., Esteban M., Giannelli L., Longinelli A., Mazzanti R., Mazzei R., Ricci Lucchi F., Salvatorini G. 1978. Some aspects of the upper Miocene in Tuscany. Messinian Seminar. Pisa, p. 88.

24. Evans G., Kirkham A. 2005. The Quaternary deposits. In The Emirates: a natural history. P. Hellyer, G. Aspinall. (Eds.) London: The Trident, pp. 65-79.

25. Francis J.E. 1983. The dominant conifer of the Jurassic Purbec Formation, England. Palaeontology. 26: 277-294.

26. Holliday D.W. 1965. Nodular gypsum and anhydrite rocks in the Billefjordan region, Spitsbergen. Nor. Polarinst., pp. 65-73.

27. Hussain M., Warren J.K. 1989. Nodular and enterolithic gypsum: the "Sabkhatization"of Salt flat playa, West Texas. Sedimentary geology. 64:13-24.

28. Kasprzyk A., Orti F. 1998. Paleogeographic and burial controls on anhydrite genesis: a case study from the Badenian basin in the Carpathian Foredeep (southern Poland, western Ukraine). Sedimentology. 45:889-907.

29. Kinsman B. 1965. Wind Waves. Englewood Cliffs. Prentice Hall, New Jersey, p. 676.

30. Lugli S., Gennari R., Gvirtzman Z., Manzi V., Roveri M., Schreiber C.B. 2013. Evidence of clastic evaporites in the canyons of the Levant Basin (Israel): implication for the Messinian salinity crisis. Journal of sedimentary research. 83:942-954.

31. Macdonald G.S. 1953. Anhydrite-gypsum equilibrium relationships. American Journal of Science. 251(12):884-898.

32. Nanfito F. 2008. Timing of Diagenesis and Deformation of Carboniferous Gypsum \&
Anhydrites in Spitsbergen. In Partial fulfillment of the requirements for the Degree. Summer, p. 62.

33. Orti F., Rosell L., Ingles M., Playa E. 2007. Depositional models of lacustrine evaporites in the SE margin of the Ebro Basin (Paleogene, NE Spain). Geologica Acta. 5(1):19-34.

34. Shearman D.J. 1966. Origin of marine evaporites by diagenesis. Transactions of The Institution of Mining and Metallurgy. 75:208-215.

35. Shearman D.J. 1985. Syndepositional and late diagenetic alteration of primary gypsum to anhydrite. Sixth International Symposium on Salt. Alexandria: Salt Institute, Vol. 1, pp. 41-50.

36. Testa G., Barbieri M., Cortecci G. 1996. The origin of Messinian evaporites from Tuscany (Italy) based on new stratigraphic and Geochemical data. 17th Regional African European Meeting of Sedimentology: abstract volume. Sfax-Tunisia, pp. 264-265.

37. Vai G.R., Ricci-Lucchi F. 1977. Algal crusts autochthonous and clastic gypsum in a cannibalistic evaporite basin: a case history from the Messinian of the Northen Apennines. Sedimentology. 24:211-244.

38. Van Driessche A.E.S., Benning L.G., Rodriguez-Blanco J.D. et al. 2012. The role and implications of bassanite as a stable precursor phase to gypsum precipitation. Science. 336 (6077):69-72.

39. Warren J.K. 1983. On pedogenic calcrete as it occurs in the vadose zone of Quaternary calcareous dunes in Coastal South Australia. Journal of Sedimentary Petrology. 29:609638.

40. Warren J.K. 1982. The hydrological setting, occurrence and significance of gypsum in late Quaternary salt lakes in South Australia. Sedimentology. 29:609-638.

41. West I.M. 1975. Evaporites and associated sediments of the basal Purbec formation (upper Jurassic) of Dorser. Proceedings of the Geologists Association. 86:205-253.

42. West I.W. 1979. Review of evaporite diagenesis in the Purbek Formation of Southern England. Symposium Sedimentation jurassique W. Europeen. 1:407-416.

43. Zamannejad A., Jahani D., Lotfpour M., Movahed B. 2013. Mixed evaporite/carbonate characteristics of the Triassic Kangan Formation, offshore area, Persian Gulf. Revista Mexicana de Ciencias Geológicas. 30(3):540551. 